to be grown by the 'disk-inoculum' method. It amplifies, but in no way supersedes, the method in general use in this Laboratory.

W. H. WILKINS.

G. C. M. HaRRIS.

Mycology Laboratory,

Department of Botany,

University, Oxford.

March 24.

1 Abraham, E. P., Chain, E., Fletcher, C. M., Florey, H. W., Gardner, A. D., Heatley, N. G., and Jennings, M. A., Lancet, ii, 177 (1941) Heatley, N. G., Biochem. $J$. (in the Press).

${ }^{3}$ Foster, J. W., and Woodruff, H. B., J. Bact., 46, 187 (1943); J. Biol. Chem., 148, 723 (1943).

-Wilkins, W. H., and Harris, G. C. M., Ann. Appl. Biol., 30, 226 (1943).

\section{Influence of Green Food on the Prevention of Piglet Anæmia}

Piglet anæmia is a microcytic hypochromic anæmia which may affect suckling pigs during the first 21-30 days after birth, especially when they are reared in such a way that access to pasture is excluded. The treatments at present adopted aim at supplying an additional amount of iron to the suckling pigs, either by dosing them individually or by allowing them access to a box of soil which is sometimes dressed with a solution of iron salts.

During the winter of 1943-44, investigations were undertaken to determine the possibility of prevention of anæmia in the suckling pigs by adjusting the diet of the pregnant sows. Four sows which had been running at pasture were housed in concrete-floored styes with open concrete-floored runs one month before they were due to farrow. The following ration was fed at the rate of $6 \mathrm{lb}$. per day during pregnancy and $10 \mathrm{lb}$. a day during the lactation period: pollards 60 per cent, beanmeal 30 per cent, fishmeal 10 per cent. To this was added 2 per cent of a mineral mixture containing calcium carbonate 35 per cent, bone ash 35 per cent, salt 18 per cent, ferric oxide (comm.) 12 per cent. Two of the sows received, in addition, two plants of marrow stem kale daily. Weaning of the litters was commenced five weeks after birth.

The litters were weighed bi-weekly and the blood of each piglet was examined at frequent intervals. In the accompanying table are shown the average values for one litter in each group at 2 days, 27-28 days and 51 days.

\begin{tabular}{|c|c|c|c|c|c|c|}
\hline$\underset{\text { (days) }}{\text { Age }}$ & $\begin{array}{c}\text { Erythro- } \\
\text { cytes } \\
\left(10^{8}\right. \\
\text { per } \\
\text { c.mm.) }\end{array}$ & $\begin{array}{l}\text { Hæmo- } \\
\text { globin } \\
\text { (gm.per } \\
100 \text { c.c.) }\end{array}$ & $\begin{array}{c}\text { Packed } \\
\text { volume } \\
\text { (per } \\
\text { cent) }\end{array}$ & $\begin{array}{l}\text { Mean } \\
\text { Corpus- } \\
\text { cular } \\
\text { Vol. } \\
\left(\mu^{3}\right)\end{array}$ & $\begin{array}{c}\text { Mean } \\
\text { Corpus- } \\
\text { cular } \\
\text { Hæmo- } \\
\text { globin } \\
(\gamma \gamma)\end{array}$ & $\begin{array}{c}\text { Mean } \\
\text { Corpus- } \\
\text { cular } \\
\text { Hæmo- } \\
\text { globin } \\
\text { Cone } \\
\text { (per cent) }\end{array}$ \\
\hline \multicolumn{7}{|c|}{ Group A. (Kale). } \\
\hline $\begin{array}{r}2 \\
28 \\
51\end{array}$ & $\begin{array}{l}7 \cdot 01 \\
5 \cdot 18 \\
6 \cdot 9\end{array}$ & $\begin{array}{r}13 \cdot 5 \\
7 \cdot 0 \\
11 \cdot 1\end{array}$ & $\begin{array}{l}50 \cdot 2 \\
32 \cdot 0 \\
46 \cdot 5\end{array}$ & $\begin{array}{l}71 \cdot 6 \\
61 \cdot 7 \\
67 \cdot 5\end{array}$ & $\begin{array}{l}19 \cdot 3 \\
13 \cdot 5 \\
16 \cdot 2\end{array}$ & $\begin{array}{l}26 \cdot 9 \\
21 \cdot 8 \\
24 \cdot 0\end{array}$ \\
\hline \multicolumn{7}{|c|}{ Group $B$ (no green food). } \\
\hline $\begin{array}{r}2 \\
28 \\
51\end{array}$ & $\begin{array}{l}4 \cdot 61 \\
5 \cdot 3 \\
6 \cdot 05\end{array}$ & $\begin{array}{l}9 \cdot 7 \\
5 \cdot 3 \\
7 \cdot 8\end{array}$ & $\begin{array}{l}34 \cdot 8 \\
24 \cdot 4 \\
30 \cdot 5\end{array}$ & $\begin{array}{l}75 \cdot 5 \\
46 \cdot 0 \\
50 \cdot 5\end{array}$ & $\begin{array}{l}21 \cdot 2 \\
10 \cdot 0 \\
12 \cdot 4\end{array}$ & $\begin{array}{l}28 \cdot 0 \\
21 \cdot 8 \\
25 \cdot 7\end{array}$ \\
\hline
\end{tabular}

The piglets in Group $A$ remained free from anæmia while those in Group $B$ became anæmic.

A preliminary trial is in progress to determine the nature of the factor or factors in the kale responsible for the effects described above.
The above is a summary of the findings of work financed by a grant from the Agricultural Research Council. It is intended to publish the findings in full elsewhere.

Institute of Animal Pathology, J. A. J. VenN. Cambridge. March 28.

\section{Viscosity and Contraction of Unstriated Muscle}

There is a close resemblance between the effects of ions on the protoplasmic viscosity of simple organisms and plants on one hand and their effects on the viscosity of unstriated muscle on the other. The viscosity of the protoplasm in these simple organisms can be measured by standard methods (for literature see ref. 1), but the viscosity of unstriated muscle is measured by comparing it to known viscous-elastic systems $^{2,3}$; the similarity of the effects on simple organisms and on muscle gives an insight into the structure of the latter, and further establishes the validity of the indirect methods for determining its viscosity.

Sodium and potassium increase, and magnesium and calcium decrease, the viscosity of the interior protoplasm of the sea-urchin Arbacia, of the protozoa Stentor and Amoba, and of the alga Spirogyra. In the cortical protoplasm of Amœba, calcium causes a pronounced stiffening of the cortical gel, and this effect is antagonized by sodium, potassium and magnesium; potassium has the strongest liquefying effect, magnesium the next and sodium has the least action. Potassium loses its liquefying action in acid solution. The effect of acids is increased in the absence of calcium.

The effects noted above were reproduced in studies of the action of ions on the viscosity of Mytilus muscle. If the sodium chloride of the saline is replaced with calcium, magnesium or potassium chlorides, the viscosity is increased in the order $\mathrm{Ca}>$ $\mathrm{Na}>\mathrm{Mg}>\mathrm{K}$. Indeed, potassium is the most powerful agent I have known for decreasing the viscosity; the effect of potassium is completely counteracted if the $p \mathrm{H}$ of the saline is reduced to $5-4 \cdot 4$. The effect of acid is increased in the absence of calcium. If smaller concentrations of potassium are used $(0.1 M$ potassium chloride), then sodium and potassium increase the viscosity, and calcium $(0.01 M$ calcium chloride) and magnesium $(0.03 M$ magnesium chloride) decrease the viscosity, as in the interior protoplasm of Amoeba.

These experiments suggest that plain muscle fibres consist at least partly of undifferentiated protoplasm like that of Amoeba. The fact that isolated myosin is effected by temperature, alkalis and distilled water in a similar way as isolated living muscle $^{3}$, as described previously, suggests that the contractile element of the muscle consists of myosin.

Plain muscle fibres thus consist of $(a)$ a viscous element, (b) a non-viscous contractile element. This view is in agreement with (1) the differential action of drugs, (2) the visco-elastic properties, and (3) the histological picture of the muscle. Thus calcium decreases the viscosity of both the guinea pig uterus and Mytilus muscle, but causes contraction of the former and relaxation of the latter. Similarly, hydrogen ions increase the viscosity of Mytilus muscle, but may cause relaxation or contraction. Lastly, histologists have described plain muscle 